Santa Clara University

Scholar Commons

Political Science

College of Arts \& Sciences

$8-22-2015$

\title{
The Fundraising Disadvantages Confronting American Political Parties
}

Anne E. Baker

Santa Clara University, aebaker@scu.edu

Follow this and additional works at: https://scholarcommons.scu.edu/poli_sci

Part of the Political Science Commons

\section{Recommended Citation}

Baker, A. (2015). The Fundraising Disadvantages Confronting American Political Parties. The Forum, 13(2), 223-244.

https://doi.org/10.1515/for-2015-0016

Copyright $@ 2015$ Walter de Gruyter GmbH. Reprinted with permission.

This Article is brought to you for free and open access by the College of Arts \& Sciences at Scholar Commons. It has been accepted for inclusion in Political Science by an authorized administrator of Scholar Commons. For more information, please contact rscroggin@scu.edu. 


\title{
Anne Baker* The Fundraising Disadvantages Confronting American Political Parties
}

DOI $10.1515 /$ for-2015-0016

\begin{abstract}
In the wake of the Bi-Partisan Campaign Finance Reform Act of 2002 and subsequent rulings by the Supreme Court, American political parties face greater regulation than interest groups in terms of their ability to finance federal elections. While parties continue to be constrained by contribution limits, nearly all interest groups can now raise and spend money in unlimited amounts to influence elections. Further, many new groups formed to take advantage of these legal changes. Few studies address the ramifications of these developments for political parties' fundraising capabilities. To see whether these disadvantages hamper party fundraising, I examine parties' direct fundraising costs overtime and I use structural equation analysis to investigate the giving habits of party donors overtime. I find the fundraising cost of each dollar raised has risen and habitual party donors provide significant support to Super PACs. Habitual party donors have also become less consistent givers in the Democratic Party. I discuss the relationship of these findings to changes in party fundraising tactics and their implications for future efforts by the parties to maintain their revenue streams.
\end{abstract}

\section{Introduction}

Changes in campaign finance law that were introduced by the Bipartisan Campaign Finance Reform Act of 2002 (BCRA) and subsequent rulings by the Supreme Court and the U.S. Federal Election Commission (FEC) have disadvantaged party organizations by limiting their ability to raise and spend money in elections while simultaneously providing unparalleled advantages to interest groups' campaign financing schemes. These regulatory changes also incentivized the formation of many new interest groups (Smith and Powell 2013). While a number of prominent studies examine the impact BCRA's regulations would and did have on political

*Corresponding author: Dr. Anne Baker, Santa Clara University, Political Science Department, 500 El Camino Real, Santa Clara, CA 95053-0335, USA, e-mail: aebaker.scu@gmail.com 
parties' finances (Dwyre and Kolodny 2003, 2006, 2014; Corrado 2006), the impact of developments post-dating the law, which lead to the asymmetric regulation of parties and interest groups, have received less attention. What remains unclear is whether competition from both a growing number and newly empowered population of interest groups has made it more difficult for the parties' national, senatorial, and congressional committees to raise money from individual donors. This study investigates the costs of party fundraising and the giving habits of party donors to determine if parties face new revenue challenges.

The Supreme Court's ruling in Citizens United v. FEC (558 U.S. 310, 2010) paved the way for interest groups to take advantage of clarified legal provisions allowing them to raise and spend unlimited amounts of money to influence elections (Smith and Powell 2013). Like interest groups, parties can make independent expenditures in unlimited amounts (518 U.S. 604, 1996; Dwyre and Kolodny 2006; Herrnson 2008, 2012; Brox 2013). However, unlike most interest groups, parties must pay for these expenditures with contributions raised in limited amounts in accordance with BCRA (See Section 307 of BCRA). Additionally, whereas parties must report all of their fundraising activities, receipts, and expenditures to the U.S. Federal Election Commission (FEC), the so called "dark money" groups including 501(c) organizations, which range from unions to social welfare organizations, as well as certain "extra-electoral"1 527 organizations only provide year-end financial summaries to the Internal Revenue Service as long as their primary purpose is not to influence elections. Parties pay higher compliance costs than these interest groups because reporting to the FEC necessitates software, accountants, legal consultations, and time. Parties must also host fundraising events and generate more fundraising appeals to raise an equivalent amount of money that a Super PAC or 501(c) organization can recruit from a single donor (Dwyre and Kolodny 2014). Thus, there is a clear connection between regulation on the one hand and fundraising capacity on the other.

As the organizations that primarily shoulder the burden of nominating candidates, informing and mobilizing voters, and setting the framework in which democratic debate occurs (Schattschneider 1941; Downs 1957; Aldrich 1995; Karol 2009; La Raja 2013), political parties perform an important public service. Unlike interest groups, which tend to advocate a narrower set of issues (Baumgartner and Leech 1998; Grossmann 2012), political parties aim to establish broad coalitions of interests in hopes of electing government officials and thereby enacting

1 Moniker created by author to distinguish these 527s from 527s, such as Swift Boat Veterans and Move On.org, that influence elections as their primary purpose and subsequently report to the FEC. 
public policies that correspond to the party's overarching ideology (Downs 1957). If political parties' fundraising operations are hampered by more extensive regulation than interest groups, then their ability to perform these functions in the service of democracy maybe undermined. Thus, an understanding of how well parties are maintaining their fundraising capacity, despite their regulatory disadvantages and despite new competition for donor contributions, is critical to any assessment of the health of American democracy.

Using data from the U.S. Federal Election Commission's itemized committee disbursement files from 2006 to 2014, I examine whether the costs of fundraising have increased for the party committees over the last five election cycles. If it costs more money to raise the same amount of money from individual donors after accounting for inflation, then that is an indication the parties face increased competition for donors' funds. In a structural equation analysis using the U.S. Federal Election Commission's individual contribution files from 2004 to 2012, I also investigate the reliability of the parties' habitual donors who contributed 54 percent of Democratic Party receipts and 78 percent of Republican Party individual receipts in 2014 and thus form the primary foundation upon which the committees' financial security and electoral influence rests (Dwyre and Kolodny 2014). ${ }^{2}$ These donors give money to the parties and to the parties' candidates in most election cycles (Francia et al. 2003, 2005). Habitual donors are analyzed according to the consistency of their contributions to their respective parties overtime and their propensity to give money to Super PACs in 2010 and 2012. I find the party's fundraising costs increased in the last two election cycles and in that timeframe many habitual party donors became Super PAC donors. Additionally, Democratic habitual donors have become less consistent contributors to the Democratic Party's committees overtime whereas habitual donors in the Republican Party maintained their support between 2004 and 2010 and increased it between 2010 and 2012.

\section{Comparing Parties and Interest Groups Under the Law}

Early scholarship on party-interest group connections by V.O. Key (1954) and E.E. Schattschneider (1941) catalyzed the debate over whether parties and

2 Percentages calculated by the author using the individual contribution files and party summary files generated by the FEC. 
interest groups operate in a competitive or cooperative relationship. Since then, the accepted conclusion in the literature is that they engage in both behaviors, particularly in elections. Parties and interest groups compete with one another for contributions from wealthy donors as well as the time and skills of political activists (Schattschneider 1941; Francia et al. 2003). And at times they recruit and support different candidates in the primary cycle (Cigler 1993; Rozell, Wilcox, and Madland 2006). At the same time, parties and interest groups also work cooperatively to achieve the election of particular candidates (Sorauf 1988; Sabato 1990; Bibby 1998; Currinder 2002; Brunell 2005; Herrnson 2005; Thomas 2005; White 2005; Cohen et al. 2008a,b; Heaney 2010; Magleby 2011a,b). Parties and party-friendly federal political action committees also promote one another's financial well-being by sharing fundraisers and fundraising advice (Birnbaum 2000) and by sharing donor lists (Koger, Masket, and Noel 2009; Masket 2009). Federal political action committees can also contribute limited amounts of funds directly to the treasuries of the parties' congressional, senatorial, and national committees, and participate in special fundraising clubs set up by the committees (Sabato 1990; Burbank, Hrebenar, and Boatright 2011).

While the boundaries between these organizations have been characterized as porous in most instances (Aldrich 1995; Thomas 2005; Herrnson 2009; Karol 2009; Witko 2009; Heaney 2010) and there is evidence to suggest that parties have played an important role in founding 527s that operate parallel campaigns to support federal candidates (Skinner 2005), it is important to acknowledge that changes in the law that prohibit coordination between independent spending groups, federal candidates, and their parties may have an impact on the extent to which these groups can cooperate with one another in the future. Moreover, parties and interest groups continue to have different goals (Brunell 2005; La Raja 2013). While they may want the same candidate to get elected, the reasons they want that candidate in office can and do differ. Additionally, parties are generally more concerned about seat-maximization than interest groups, many of which have much narrower issue-centered policy goals. Since the evidence cited above suggests interest groups at least some of the time are competitors for electoral resources, the legal disadvantages the parties now face merit special attention.

Most significantly, the Bipartisan Campaign Finance Reform Act of 2002 (BCRA) banned parties from raising and spending soft money (See Section 101 of BCRA) - funds not subject to federal contribution limits because they are not being spent directly in support of federal candidates (Corrado et al. 2005; Malbin 2006; Powell 2010). Rather, these monies paid for issue advertisements and getout-the-vote efforts the parties claimed indirectly supported the candidate's race (Powell 2010; Brox 2013). BCRA closed this important loophole for parties thereby effectively eliminating over half of their revenue flow (Corrado et al. 2005; Malbin 
2006; Powell 2010). Despite this, the parties' congressional, senatorial, and national campaign committees were able to make up for the loss of soft money by raising larger amounts of hard money (Dwyre and Kolodny 2003; Corrado 2006; Malbin 2006; Salant 2012), which are dollars raised at the federally proscribed contribution limits.

BCRA also banned corporations and unions from using money from their general treasuries to support or oppose candidates contesting in federal elections even when those expenditures were made independently from the candidate's campaign (Potter 2006; Malbin 2006). This ban did not last long. In keeping with its previous rulings in Buckley v. Valeo (424 U.S. 1, 1976) and Massachusetts Citizens for Life, (479 U.S. 238, 259, 1986) the Supreme Court, which in its opinions in these cases strongly associated independent spending with freedom of expression rights, overruled the prohibition on corporate, union, and issue advocacy groups' independent spending in the case Citizens United in January of 2010. Subsequent cases, such as SpeechNow [Civ. No. 08-5223 (D. D.C. 2010)] and Carey v. FEC [Civ. No. 11-259-RMC (D. D.C. 2011)] further loosened the restrictions on political committees allowing them not only to make independent expenditures in unlimited amounts but to raise unlimited contributions -from individuals, corporations or unions -to fund political messages to aid their preferred candidates as long as they did not directly contribute money to the federal candidate's campaign or coordinate with the campaign in any way (Rozell, Wilcox, and Madland 2006; Smith and Powell 2013). Although parties can make independent expenditures in unlimited amounts, they must pay for those expenditures with funds that are raised in legally limited amounts from individual donors and federal political action committees.

The new precedent that independent speech could not be regulated based upon the entity expressing itself also spurred the creation of many new PACs and 501(c) groups (Smith and Powell 2013). Independent-expenditure only PACs, or Super PACs as they have come to be called, must register with the FEC and are subject to all of the disclosure requirements as other committees under BCRA if their major purpose is to influence federal elections. There are also 501(c) groups, which range from unions to social welfare organizations, that are not subject to these requirements as long as their primary purpose is issue advocacy but not the support or defeat of federal candidates and there are also certain "extraelectoral" 327 organizations that only report year-end fundraising totals to the

3 Moniker created by author to distinguish these 527s from 527s, such as Swift Boat Veterans and Move On.org, that influence elections as their primary purpose and subsequently report to the FEC. 
Internal Revenue Service as long as their primary purpose as stated on IRS form 8871 is not to influence elections. Whereas Super PACs must disclose all of their donors quarterly, 501(c)s and "extra-electoral” 527s are not required to disclose their donors at all (Taylor and Holman 2010; Smith and Powell 2013). This advantage has earned them a bad reputation as "dark money groups" because independent expenditures by these groups are most typically used to pay for radio and television advertisements, which usually air without clear ties to recognizable organizations (Smith and Powell 2013).

According to a report by the Treasury Inspector General for Tax Administration (2013), the number of new groups seeking 501 tax-exempt status has risen since 2009. New applications for status as 501(c)4 social welfare organizations rose from 1751 in 2009 to 3357 in 2012. Similarly applications for 501(c)5 labor and agricultural organizations rose from 543 to 1081 and for 501(c)6 professional associations from 1828 to 2338. Additionally, U.S. Federal Election Commission reports indicate that the number of registered Super PACs grew from 83 in 2010 to 1262 in 2012. These entities rely almost exclusively upon independent expenditures.

In addition to 501(c) and Super PACs, parties also face new competition from any unlikely source: the political action committees that formed after the adoption of the Federal Election Campaign Act of 1971. For a time, these committees, like the parties, were only permitted to raise and spend hard dollars in federal elections. And, like the parties, they were barred from raising and spending soft money even after Citizens United (2010) and subsequent rulings, that is, until Carey v. FEC (2011). Carey v. FEC (2011) gave non-connected ${ }^{4}$ political action committees the ability to set up separate bank accounts for soft money contributions from individuals, corporations, and labor unions while at the same time collecting hard dollar contributions in another account at federally proscribed limits for direct contributions to federal races.

The parties' congressional, senatorial, and national campaign committees were given none of these new privileges. As a consequence, the party committees are the only organizations in American elections that cannot raise money in unlimited amounts for independent expenditures. Political parties must continue to disclose the names of all of their contributors who make contributions in excess of \$200 (See Section 103 of BCRA). This means parties must not only pay greater heed to the sources of their contributions but they are also subject to

4 There are connected and non-connected PACs. Non-connected PACs are not connected to an organization, such as a professional association or issue advocacy group, that has goals beyond influencing elections. Non-connected PACs' sole purpose is raising hard money at the legal limits to influence elections via direct contributions to parties and federal candidates. 
more burdensome reporting requirements that take time and resources to fulfill. In sum, the parties cannot legally participate in the "dark money" game. To determine whether party fundraising has suffered as a consequence of the rise of newly advantaged interest groups, the costs related to party fundraising and the stability of the parties' individual donor bases are examined.

\section{Data and Methods}

For the analysis of parties' fundraising costs, operating expenditure files from the U.S. Federal Election (2006-2014) featuring itemized disbursements from Form 21B are utilized to identify expenditures made by the parties' congressional, senatorial, and national committees that are directly related to fundraising. Although the party committees must pay for all of their operating costs using hard dollar fundraising revenues, the goal of the analysis is to determine whether direct investments in fundraising aside from other operating expenditures provide maximum returns. Direct investments in fundraising include expenditures on fundraising events, such as catering and entertainment designed to recruit large contributions from donors as well as expenditures on direct mail programs that are intended to raise money from small dollar donors. Direct fundraising expenditures were identified in the files and aggregated by election cycle. Committee expenditures such as employees salaries, office supplies, rent for office buildings, and polling costs were not included in these totals. The FEC's 2 year party summary files are also used to glean the total individual contributions each party committee received in each election cycle. Both sets of aggregated sums were then placed in 2006 constant dollars. Total fundraising expenditures are divided by total fundraising revenues from individuals to calculate the fundraising cost per dollar raised.

For the analysis of habitual donors' giving habits, all contribution data are collected from the U.S. Federal Election Commission's (FEC) itemized committee files between 2004 and 2012. Individual donors are divided into Democratic and Republican camps on the basis of whether the donor made a direct contribution to at least one of the parties' national committees (Democratic National Committee; Republican National Committee; Democratic Senatorial Campaign Committee; National Republican Senatorial Committee; Democratic Congressional Campaign Committee; National Republican Congressional Committee) between 2004 and 2012. Donors who made contributions to both parties are not included in analysis. After these donors were excluded the remaining donor pools numbered approximately 286,345 for the Democratic Party committees and 331,971 for the Republican Party committees. Reported hard dollar contributions are \$200 
and greater. Individual donors are limited by campaign finance law in terms of not only how much money they can contribute directly to candidates, parties, and interest groups as individual entities ${ }^{5}$ but also by how much they can give in total over the course of the election cycle to all three of these entities. The global contribution limit in 2006, the lower bound of this dataset, was $\$ 101,400$, and the cap for 2012, the upper bound of this dataset, was $\$ 117,000$ per 2-year cycle. ${ }^{6}$ A donor is classified as habitual after making at least one contribution to at least one of the party committees in at least two different election cycles between 2004 and 2012. Donors' names, occupations, and address information were used to identify Super PAC contributions that were made in 2010 and/or 2012 by those donors who were identified as habitual donors following the procedure discussed above. All monies are placed in 2004 constant dollars so comparisons across election cycles can be made.

The goal of the donor analysis is to determine the degree to which an individual donor will contribute to the party from 1 year to the next while accounting for the total effects previous contributions have on the donor's degree of party support. Additionally, the analysis tests whether habitual donors were more or less likely to provide contributions to Super PACs in 2010 and 2012 when a majority of those groups first entered electoral politics in direct response to the Supreme Court's ruling in Citizens United. On the one hand, habitual donors, as the most constituent and loyal party donors, might be expected to refrain from giving to Super PACs, which might be viewed as less established and therefore less reliable repositories for their contributions. On the other hand, habitual donors clearly have the resources and enough political experience to take advantage of other avenues to influence elections (Francia et al. 2003, 2005). The difficulty in performing these tests is that party contributions from one year to the next will be highly correlated. In a regression analysis, multicollinearity would make it difficult to determine whether the consistency of donor giving declined overtime because the magnitude of each coefficient will be artificially

5 In 2006, an individual donor could give a maximum of $\$ 2100$ to each candidate per election, $\$ 26,700$ to a national party committee per year, $\$ 10,000$ to state, district or local party committees per calendar year, and a maximum of $\$ 5000$ to a political committee per each calendar year (FEC Record March 2006). In 2012, an individual donor could give a maximum of $\$ 2500$ to each candidate per election (primary and general are counted separately), $\$ 30,800$ to a national party committee per calendar year, $\$ 10,000$ to state, district or local party committees per calendar year, and a maximum of $\$ 5000$ to a political committee per each calendar year (FEC Record March 2012). Contributions to candidates and parties are adjusted for inflation in odd-numbered years in accordance with the Bi-partisan Campaign Finance Reform Act of 2002.

6 This total includes $\$ 46,200$ to all candidates and $\$ 70,800$ to all PACs and parties. 
inflated by the other party contribution covariates. Similarly, party contributions and Super PAC contributions may be endogenously related because of alliances between the parties and certain Super PACs and mutual recruitment of the same donors. As a consequence of these issues, which cannot be overcome by regression analysis, I employ structural equation modeling. Using path analysis, structural equation modeling (SEM) examines the impact of exogenous variables on endogenous variables and the effect of different endogenous variables on one another (Golob 2001; Price and Collet 2012, p. 13). Using this approach, the direct, indirect, and total effects of individual contributions to the parties on the one hand and parties' fundraising efforts on the other can be simultaneously evaluated in relation to the degree of support habitual donors provide to super PACs.

Unfortunately for the purposes of this analysis, the parties' itemized disbursements do not include descriptions providing the location of fundraising events. In fact itemized disbursements are rarely labeled in the files as being tied to specific events. Fundraising effects are also endogenously related to party contributions. Fundraisers will host events in areas where donors are likely to contribute and donors are more likely to contribute if solicited. As a consequence, proxy measures for fundraising efforts affecting individual donors' likelihood of contributing must be utilized. I include variables in the path analyses for the number of competitive House and Senate races in the donor's state for each election cycle in the dataset and, in presidential election cycles, I include a dummy variable indicating if the donor resides in a battleground state. Both variables should reflect the likelihood that party fundraisers will take place where the donor lives. These measures have the added benefit of capturing electoral competiveness and related excitement surrounding a given election cycle that is known to increase contributions from individuals to the parties (Herrnson 2012).

Lastly, it bears noting that since a primary goal of SEM analyses is to find the best model to fit the data, several statistics are relied upon to assess goodness of fit. The Comparative fit indices (CFI), the Tucker-Lewis fit index (TFI, also known as the non-normed fix index), and the root mean square error of approximation (RMSEA) are used to compare the fit between the hypothesized models and the observed data - examining more than one fit statistic is highly recommended. The benchmark for both the CFI and TLI indices is 0.9 or higher. RMSEA measures the portion/percentage of variance that the structural system of equations does not explain. The RMSEA values 0.01, 0.05, and 0.08 are used to indicate excellent, good, and adequate fit, respectively (MacCallum, Browne and Sugawara 1996; Kenny 2014). These fit statistics are reported in the tables below. 


\section{Party Fundraising Costs and Donor Retention}

The results of the fundraising cost analysis are presented in Figure 1. The graph shows the dollar cost of fundraising associated with each dollar raised from individual donors. Since all monies are in constant 2006 dollars, it is possible to compare the cost per dollar raised for different election cycles. For the congressional committees, the cost of raising money rose between 2006 and 2014 - from 2 to 9 cents for the DCCC and from 4 cents to 28 cents for the NRCC. The lower fundraising costs for the DCCC are particularly impressive because the committee has outraised the NRCC by an average of \$41 million since 2006 (Dwyre and Kolodny 2014). For the senatorial committees, the results differ even more extremely by party. The DSCC spent an average of 3 cents for each dollar raised in 2006 and 20 cents in 2014. The NRSC has had more difficulty retaining a fundraising edge since the 2000 election cycle (Dwyre and Kolodny 2014) and the committee had a particularly bad year in 2008 in which it cost the committee 67 cents to raise a dollar. That year the committee's gross profit margin was also a meager 33 percent compared to the committee's usual gross profit margins of 80 percent. The committee's poor financial performance can be attributed to the Republican's difficult position in the 2008 Senate election in which they had almost double the number of seats to defend than the Democrats. Vulnerable Republican incumbents recruited funds directly from individual donors, which may have undercut the NRSC's revenue margin. In other election cycles, the committee's weak fundraising has been largely attributed to a "long-standing reluctance [among] incumbent Republican senators to transfer funds to the committee" (Dwyre and Kolodny 2014, p. 187). At any rate, the NRSC is the only committee to have seen its fundraising costs substantially decline between 2006 and 2014 - but the reality is that its performance was so weak it could only improve

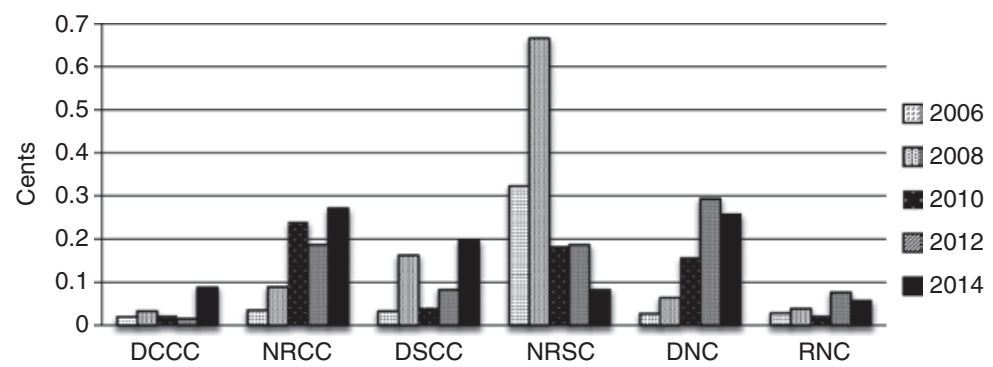

Figure 1: Direct Fundraising Cost Per Dollar Raised. Note: All monies in 2006 constant dollars. 
those cost margins. For the DNC and RNC, the cost per dollar raised was much higher in 2012 and 2014 than in pervious election cycles. The DNC spent 29 cents per dollar raised in 2012 and 26 cents per dollar raised in 2014 and the RNC spent 8 cents per dollar raised in 2012 and 6 cents per dollar raised in 2014 in comparison to the 3 cents per dollar both committees spent in 2006. The RNC has a clear cost margin advantage especially in light of the fact that RNC raised \$24.9 million more than the DNC from individual donors in 2014. Despite variations in cost per dollar raised, it bears noting that all of the committees generally perform better than the national average for non-profits of 20 cents per dollar raised (Greenfield 1999). Still, every committee except the NRSC saw fundraising costs increase since 2006.

The results of the SEM analysis are displayed in Tables 1 and 2. Diagrams of each path analysis can be found in the Appendix (see Figures A1 and A2). The total effects of party giving on super PAC giving in 2010 and 2012 and super PAC giving on party giving in 2012 are displayed in Table 1. The direct effects associated with both forms of giving are displayed in Table 2. These models were specified after a series of revisions to improve fit until the best model was identified. In the final models shown in Figures A1 and A2 in the Appendix, super PAC giving and party giving in 2010 and 2012 are specified as endogenous to one another. Since the parties formed alliances with some super PACs (as suggested by Smith and Powell 2013), this outcome is not surprising. Additionally, previous research on donors suggests that habitual donors often have connections to many other political organizations (Francia et al. 2003, 2005). Thus, they are predisposed to make political contributions in general and thanks to their connections are also likely to be solicited by super PACs. While some super PACs maybe allies and others competitors, determining whether super PACs place a drain on parties' habitual donor pools is still of interest because ideally from the parties' standpoint super PAC allies would not infringe upon their fundraising capacity. These aspects of the results are discussed below. What remains clear is that the fit of the models featuring this endogenous relationship is quite good (see Table 1). The RMSEA for the Republican model of donor giving is 0.010 with CFI And TFI indices well above 0.9 all of which indicate the model fits the observed data extremely well. The Democratic model does not fit the data quite so well as the Republican model. Although the RSMEA of 0.015 suggests the model is a good fit, the CFI and TFI indices are at the 0.9 benchmark for acceptable fit (see MacCallum, Browne and Sugawara 1996; Kenny 2014). Taken together, however, these statistics indicate the Democratic model can be reliably utilized for inference. The primary relationships of interest are discussed below whereas the total and direct effects for the proxy variables for fundraising and electoral competitiveness are discussed in the appendix. 


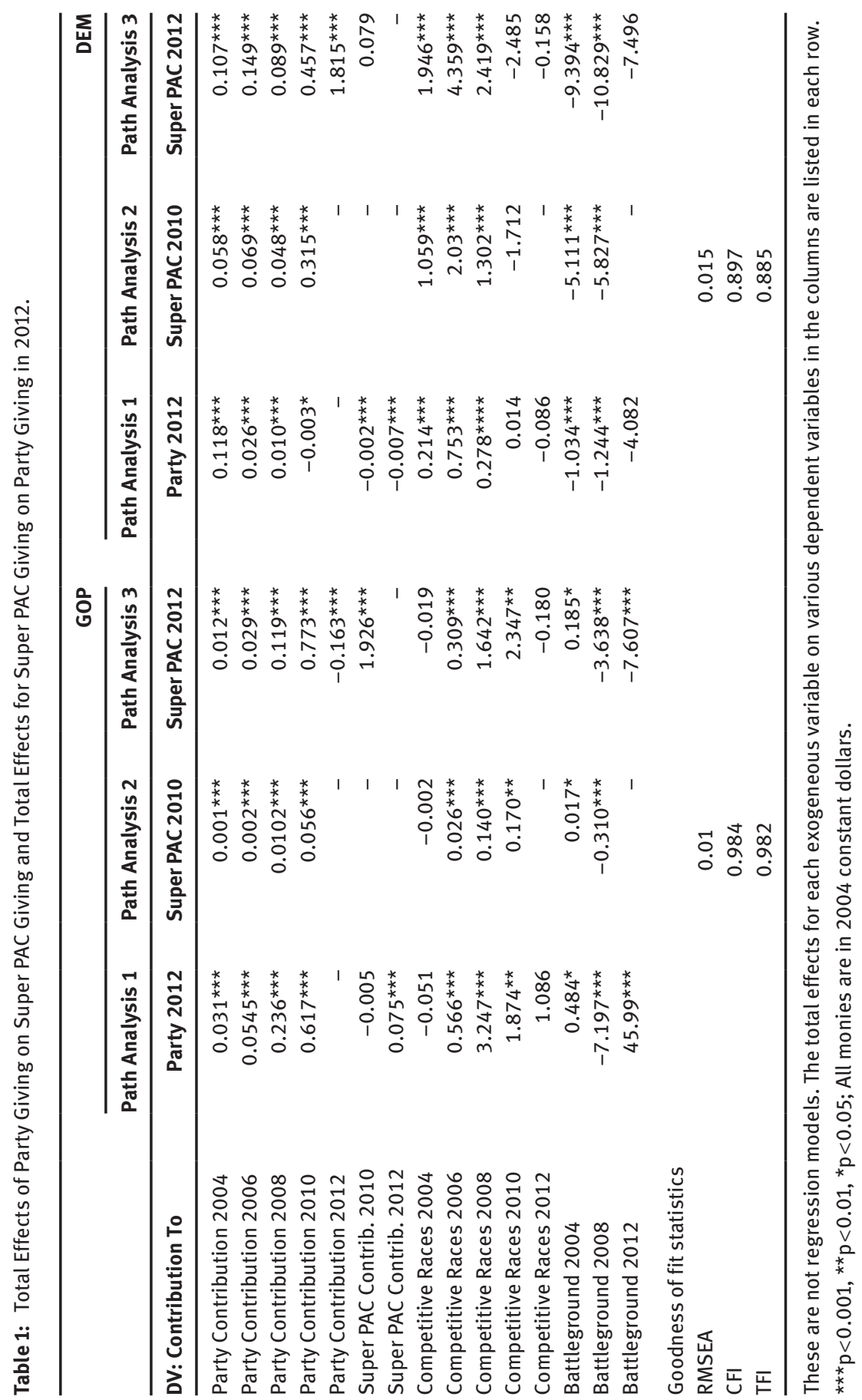


Table 2: Direct Effects Party and Super PAC Giving.

\begin{tabular}{|c|c|c|}
\hline Pathway & GOP & DEMS \\
\hline pty04->pty06 & $0.257^{\star \star \star}$ & $0.310^{\star \star \star}$ \\
\hline pty06->pty08 & $0.212^{\star \star \star}$ & $0.0464^{\star \star \star}$ \\
\hline pty08->pty10 & $0.181^{\star \star \star}$ & $0.152^{\star \star \star}$ \\
\hline pty10->pty12 & $0.567^{\star \star \star}$ & $0.003^{*}$ \\
\hline pty10->super10 & $0.056^{\star \star \star}$ & $2.235^{\star \star \star}$ \\
\hline pty10->super12 & $0.765^{\star \star \star}$ & $0.279 * \star \star$ \\
\hline pty12->super12 & $-0.165^{\star \star \star}$ & $1.837^{\star \star \star}$ \\
\hline super10->pty10 & $-0.271^{\star \star \star}$ & $-2.727^{\star \star \star}$ \\
\hline super12->pty12 & $0.075^{\star \star \star}$ & $-0.007^{\star \star *}$ \\
\hline super10->super12 & $2.162^{\star \star \star}$ & $1.342^{\star \star \star}$ \\
\hline
\end{tabular}

${ }^{* * *} \mathrm{p}<0.001,{ }^{* *} \mathrm{p}<0.01,{ }^{*} \mathrm{p}<0.05$.

Theta coefficients the same as those presented in Figures $A 1$ and $A 2$ in the appendix.

The first relationship of interest is whether habitual party donors proved likely to contribute to super PACs in 2010 and 2012 when the number of these groups surged in response to the Supreme Court's ruling in Citizens United. In Table 1, the positive and significant coefficients in the super PAC path analyses 2 and 3 for both Republican and Democratic donors indicates these donors likely made contributions to super PACs. For Democratic donors, a one standard deviation increase in party giving results in a predicted standard deviation increase ranging from 0.06 to 0.32 in super PAC giving in 2010 and between a 0.11 and 1.8 standard deviation increase in 2012. The coefficients representing the total effects of party giving in each preceding election cycle only increase indicating the more frequently the donor contributed to the Democratic party the more that donor is likely to contribute to a super PAC in both 2010 and 2012. In constant 2004 dollars, this means a one standard deviation increase in party contributions of \$1412 in 2012 results in a predicted 1.8 standard deviation increase in Super PAC giving from the mean amounting to $\$ 47,757$ being given to a super PAC by the donor, all else equal. In turn, habitual donors who gave money to super PACs in 2010 and 2012 are less likely to support to the party committees in those election cycles (see Table 1 Path Analysis 1). The direct effects of super PAC giving on party support are highly significant and negative in Table 2 indicating the more the donor gives to super PACs the less that donor is predicted to give to the party committees.

For Republican donors in 2010, the results follow a similar pattern, although the magnitude of the effect is smaller (see Table 1, Path Analysis 2, e.g. $\beta=0.001$ for the total effect of party contributions in 2004 on Super PAC giving in 2010 whereas for Democrats $\beta=0.058$ ). A one standard deviation increase in contributions to 
the Republican party committees in a given election year - on average a sum of $\$ 2357$ - results in a predicted standard deviation increase in super PAC giving between 0.001 and 0.056, all else equal (see Table 1, Path Analysis 2). In 2010, this means a Super PAC is predicted to receive an additional \$30 for every \$2357 the donor contributes to the party. While habitual Republican Party donors are also likely to contribute to super PACs in 2012 if they previously gave money to the party, this is not the case for any party contributions the donor specifically made in the 2012 election cycle. The analysis in Table 2 - which shows the direct effect of contributing to the party on the degree of support a donor provides to a Super PAC - reveals a negative relationship between party support and super PAC giving in 2012 ( $\beta=-0.165$ in Table 2 and $\beta=-0.163$ in Path Analysis 3 in Table 1). Despite this exception, Republican donors like their Democratic counterparts are more likely to contribute to Super PACs if they gave to the party committees in previous election cycles. For instance, in Table 2, Republican donor's party contributions in 2010 are predicted to increase their contributions to Super PACs in 2010 and in 2012 ( $\beta=0.056$ and $\beta=0.765)$. Taken as a whole the evidence suggests habitual donors in both parties have become super PAC donors.

The next question to address is whether habitual donors have become less consistent givers to the party committees overtime. If so, this is another indication that the party committees face new fundraising challenges that may be related to the rise of so many new interest groups. The direct effects of party giving from one election to the next are examined in Table 2. For Democrat donors, the coefficients decline both in magnitude and significance between 2004 and 2012 ( $\beta=0.310$ in 2004 versus $\beta=0.003$ in 2012). The same pattern is evident for the total effects of giving in each election cycle on party contributions in 2012 (see Table 1, Democratic Path Analysis 1). The opposite is true for Republican donors. In Table 2, the direct effects of making a contribution to the party in one election cycle on making a contribution to the party in the following election cycle remain fairly constant in magnitude between 2004 and $2010(\beta=0.257, \beta=0.212$, and $\beta=0.181$ ). However, between 2010 and 2012, the direct effect of party giving jumps to $\beta=0.567$ suggesting something caused habitual donors to commit even more money to Republican Party's committees.

\section{Party Fundraising in the New Regulatory Environment}

Parties face a number of fundraising challenges in the post-Citizens United regulatory environment. The cost of raising a dollar from individual donors 
has increased for most of the party committees. Some committees have faired worse than others. In 2014, fundraising costs for the NRCC and DNC exceeded the national average cost per dollar raised of 20 cents and fundraising costs for DSCC and NRSC came close (see Figure 1). An examination of the total individual receipts raised by each party reveals a struggle to maintain 2004 revenue levels while simultaneously coping with rising fundraising costs. As shown in Figure 2, Republican individual receipts have ebbed and flowed over the time period with a marked decline between 2008 and 2014. While in 2014 the Democrats were able to surpass record levels of individual fundraising that were achieved in 2004 (Dwyre and Kolodny 2014), prior to 2014 their revenue stream from individual donors exhibited similar instability.

Although the Democratic Party organizations were able to raise $\$ 111$ million more from individual donors than the Republican Party organizations combined in 2014 (see Figure 2), the results of the habitual donor analysis suggest the Democratic committees face more challenges to maintain their habitual donor bases. Democratic donors contributing habits became less consistent overtime. Contributions to the party in one election became less predictive of contributions to the party in subsequent election cycles - this trend arose even before habitual donors had the opportunity to make contributions to super PACs. In contrast, between 2004 and 2010, Republican donors maintained their financial support of the party committees from one election cycle to the next. In 2010 and 2012, they expanded their financial support to super PACs as well as the party committees. Thus, the rise of super PACs does not appear to have affected their fundraising returns from habitual donors.

The Democrats lower fundraising costs on average and higher overall receipts from individuals in 2014 appear to be at odds with the observed decline in Democratic habitual donors' contributions overtime. However, there is a simple explanation for these seemingly disparate sets of findings. Beginning in 2004 the

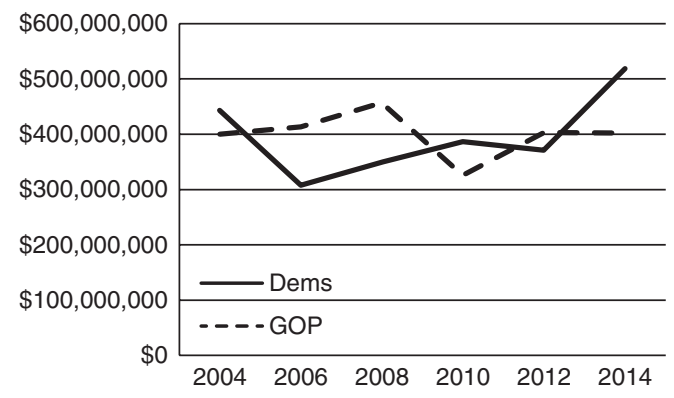

Figure 2: Total Individual Receipts to Party Organizations. 
Democrats made major investments in their direct mail programs designed to recruit funds from small dollar donors and they began to make better use of the Internet, email, mail, text messaging, and social networking sites to recruit small dollar gifts (Dwyre and Kolodny 2014). The low cost of Democratic fundraising is attributable to their reliance upon small dollar contributions raised by these low cost solicitations (Dwyre and Kolodny 2014). As a consequence, fundraising costs were lower for the DCCC and DSCC than the NRCC and NRSC. This is particularly significant because the two Democratic committees have been able to outraise the Republican committees since 2006 (Dwyre and Kolodny 2014).

Conversely, the results of the habitual donor analysis show Republican committees were able to successfully retain their habitual donors overtime even as super PACs arose and convince these donors to commit more money to the committees in 2012. These trends are likely the direct result of the Republicans' change in fundraising tactics. Between 2010 and 2012 Republican committees focused their efforts on collecting the maximum contribution from a larger number of habitual donors (limits ranging from $\$ 26,700$ in 2006 to $\$ 32,400$ in 2014) with great success (Dwyre and Kolodny 2014). In 2012 the RNC collected more than four times the amount of money from maxed-out donors than the DNC and the NRSC collected \$6.2 million more from maxed out donors than the DSCC (Dwyre and Kolodny 2014). These fundraising efforts are reflected in the habitual donor analysis for Republican donors. In Table 2, party contributions in 2010 more strongly predicted party contributions in $2012(\beta=0.567)$ than the previous midterm-presidential election year pairings. This suggests Republican donors increased their party support in 2012 most likely in response to solicitations by the RNC and NRSC.

In sum, the Democrats have done more to expand their individual donor bases while the Republicans have made greater efforts to cultivate existing habitual donors. Going forward both parties should commit equally to both tactics especially because a major limitation of this study is that it is not possible to know how much money both habitual and small-dollar donors are diverting to "dark money" groups in addition to super PACs. The results suggest both tactics come with specific benefits.

The Republicans cultivation of habitual large-dollar donors may pay off in future election cycles due to the Supreme Court's decision to overturn the global contribution limit. By overturning the global caps in McCutcheon v. Federal Election Commission (U.S. Supreme Court Docket No. 12-536, 2012, 2), the Court provided the parties with the opportunity to raise more than the global cap of $\$ 123,200$ from a pool of approximately 700 maxed out donors in 2012 (Cillizza 2014). However, there is reason to believe any fundraising increases resulting from the elimination of the fundraising cap may not be enough to enable parties 
to compete effectively with super PACs and 501c groups for contributions from individual donors. First, parties continue to be subject to disclosure requirements under BCRA whereas 501c and some 527 groups are not. Unlike Super PACs and 501c groups, parties still must raise contributions for their own treasuries and those of candidates at the legally proscribed limits or at least earmark portions of a large contribution within those limits. A party committee wishing to collect funds on behalf of a candidate or an allied interest group as well as its own operations would need to set up a joint fundraising committee for that purpose. On the one hand, while this could strengthen the ties between parties and interest groups or parties and campaigns, on the other, conflicts could arise within party networks over how to fairly distribute contributions raised at events hosted by a joint committee (Interview, Non-Connected PAC Senior Staff 6/13/14). ${ }^{7}$ Unfortunately, the precedent in $\mathrm{McC}$ utcheon also provides federal PACs the same bundling advantages as parties making parties one of many groups soliciting additional funds from the wealthiest donors. Additionally, when non-connected PACs solicit additional funds they can easily place any additional non-earmarked monies that exceed the contribution limits for the individuals and groups they support into their segregated soft money account - a option no longer available to the party committees. Finally, it is not clear how many donors out of the current pool of 700 donors who engage in hard-dollar giving at the legal maximum (Cillizza 2014) will want to take advantage of the elimination of the aggregate limit rather than give money anonymously to independent expenditure committees in unlimited amounts to support their favorite candidates and issues. While it by no means clear that this ruling with provide the parties with significant new fundraising advantages, an opportunity is certainly there to raise more money from individuals.

Even if the conditions discussed above are met and the Court's decision provides the parties with a way to substantially increase revenues, the results suggest super PACs might still be a drain on party donor pools. Rather than scorning Super PACs, habitual donors of both parties appear to have embraced these groups as a

7 Although in the past joint fundraising committees typically agreed to contracts prior to hosting joint fundraising events in which a division of funds was specified, such formulas will be more difficult to negotiate without global caps on how much an individual can give. Disputes could arise over excess funds because the total amount of an unrestricted contribution must still be distributed to each receiving organization at the legal limit. One could easily imagine the party committee wanting the excess money to go to other party organizations or particular candidates whereas the interest group might want the money to go to several allied groups and a different set of candidates. 
new way to influence politics. As a consequence, the Democrats' choice to devote time and resources to recruit small dollar contributions could represent a good way to maintain party revenue streams because most super PACs, 501c organizations, and 527s, rely upon large-dollar donors as their primary source of revenue rather than small dollar fundraising (Skinner 2005; Smith and Powell 2013).

While the parties appear to have maintained their fundraising capacity in spite of new competition from groups enjoying fewer regulatory burdens, they are now placed in a position in which they have to continually do more to remain relevant financiers of elections. Previous studies point to opportunities for parties to form alliances with super PACs, 501c, and 527 organizations and the benefits associated with the "shadow campaigns" of these groups in support of party electoral goals (Skinner 2005; Herrnson 2009). Dwyre and Kolodny (2014) note Super PACs and 501c organizations encourage donors to contribute to candidates and parties because "of more favorable rules for campaign expenditures and because of the ability of candidates and party committees to coordinate" (p.179). However, the results presented here suggest minimal reciprocity exists between the parties and super PACs. In 2010, contributions to super PACs were associated with smaller contributions made by those donors to both Republican and Democratic Party committees (see Table 2). In 2012, this trend continued for the Democrats but reversed for the Republicans probably as a consequence of their efforts to cultivate habitual large-dollar donors who are also the fundraising targets of super PACs (Dwyre and Kolodny 2014). As a consequence, the parties may need to find other ways to expand and maintain their individual donor bases. The evidence of their adaptability presented here and elsewhere suggests they will manage to maintain a pivotal role in campaign financing even while shouldering a disproportionate regulatory burden. While the parties are disadvantaged, they have not become defunct.

\section{Appendix}

The proxy variables for fundraising and electoral competitiveness at the state level also contribute to the good fit of the models. The number of competitive races in the state where the party donor resides increases the chances a donor will make a contribution to one of the committees (see Table 1). Any negative coefficients associated with this variable are not significant (see Table 1). The dummy variable for battleground states varies by party in terms of its impact. For Republican donors, living in a battleground state in the presidential election increases their contributions to the party in 2004 and 2012 but not in 2008. There was little 


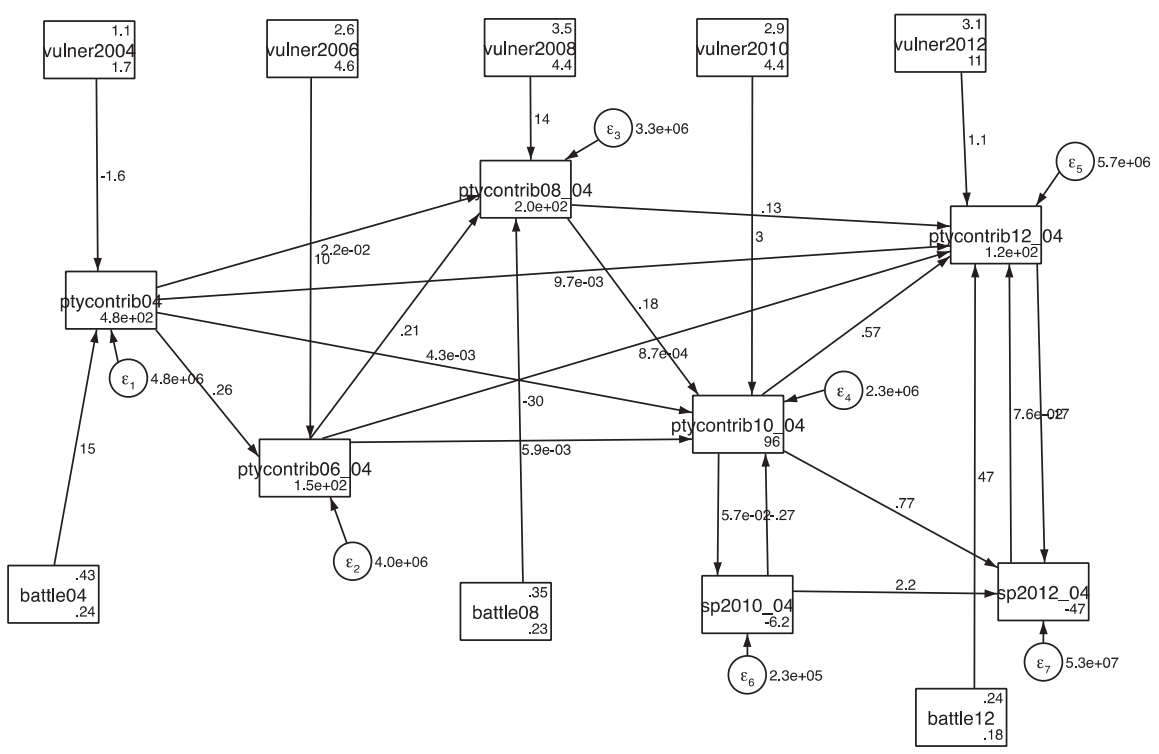

Figure A1: Path Analysis of Republican Habitual Party Donors Party and Super PAC Giving. Note: All monies in 2004 constant dollars. Vulner, Number of competitive races for House and Senate; Party Contrib, Total hard dollar contributions to congressional, senatorial, and national party committee; sp, super PAC contributions; Battle, donor contributing from battleground state.

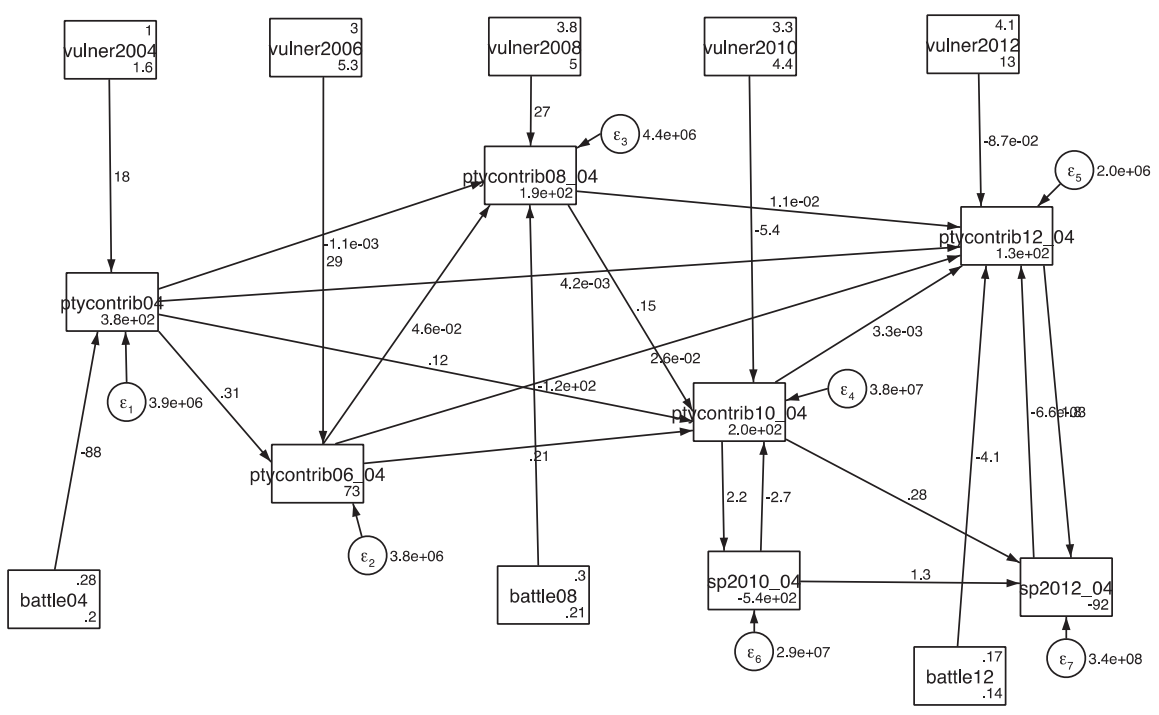

Figure A2: Path Analysis of Democratic Habitual Party Donors Party and Super PAC Giving. Note: All monies in 2004 constant dollars. Vulner, Number of competitive races for House and Senate; Party Contrib, Total hard dollar contributions to congressional, senatorial, and national party committee; sp, super PAC contributions; Battle, donor contributing from battleground state. 
overlap between states from which the most Republican contributions stemmed and battleground states in the 2008 election. This was true for the Democrats in all three presidential election cycles. As a consequence, the coefficients for the battleground state dummy variables are negative in all of the Democratic models (see Tables 1 and 2). These results support the idea that party contributions are tied to both the competitiveness of the election and the number of fundraisers the party hosts in the donor's state. The path analysis diagrams for the Republican and Democratic SEM analyses are above (see Figures A1 and A2).

\section{References}

Aldrich, John. 1995. Why Parties? The Origin and Transformation of Political Parties in America. Chicago, IL: University of Chicago Press.

Baumgartner, Frank, and Beth Leech. 1998. Basic Interests: The Importance of Groups in Politics and Political Science. Princeton, NJ: Princeton University Press.

Bibby, John. 1998. “Party Organizations, 1946-1996." In Partisan Approaches to Postwar American Politics, edited by Byron Shafer, 142-185. New York: Chatham House Publishers.

Birnbaum, Jeffrey. 2000. The Money Men: The Real Story of Fundraising's Influence on Political Power in America. New York, NY: Crown.

Brox, Brian J. 2013. Back in the Game: Political Party Campaigning in an Era of Reform. Albany, NY: SUNY Press.

Brunell, Thomas. 2005. “The Relationship Between Political Parties and Interest Groups: Explaining Patterns of PAC Contributions to Candidates for Congress." Political Research Quarterly 58: 681-688.

Burbank, Matthew, Ronald Hrebenar, and Robert Boatright. 2011. Parties, Interest Groups, and Political Campaigns. UK: Oxford University Press.

Cigler, Allan. 1993. "Political Parties and Interest Groups: Competitors, Collaborators, and Uneasy Allies.” In American Political Parties, A Reader, edited by Eric M. Uslaner. Itasca, IL: F.E. Peacock.

Cillizza, Chris. 2014. "Winners and Losers from the McCutcheon v. FEC Ruling." Washington Post, Accessed May 31, 2014. http://www.washingtonpost.com/blogs/the-fix/ wp/2014/04/02/winners-and-losers-from-the-mccutcheon-v-fec-ruling/.

Cohen, Marty, David Karol, Hans Noel, and John Zaller. 2008a. "Political Parties in Rough Weather." The Forum 5: Article 3.

Cohen, Marty, David Karol, Hans Noel, and John Zaller. 2008b. The Party Decides; Presidential Nominations Before and After Reform. IL: University of Chicago Press.

Corrado, Anthony. 2006. "Party Finance in the Wake of BCRA: An Overview." In The Election After Reform: Money, Politics, and the Bipartisan Campaign Reform Act, edited by Michael Malbin, New York, NY: Rowman and Littlefield Publishers, Inc.

Corrado, Anthony, Thomas Mann, Daniel Ortiz, and Trevor Potter. 2005. The New Campaign Finance Sourcebook. Washington DC: Brookings Institution Press.

Currinder, Marian. 2002. Money in the House: Campaign Funds and Congressional Party Politics. Denver, CO: Westview Press. 
Downs, Anthony. 1957. An Economic Theory of Democracy. New York, NY: Harper.

Dwyre, Diane, and Robin Kolodny. 2003. "National Parties After BCRA." In Life After Reform:

When the Bipartisan Campaign Reform Act Meets Politics, edited by M. J. Malbin, 83-100. New York, NY: Rowman and Littlefield Publishers, Inc.

Dwyre, Diane, and Robin Kolodny. 2006. "The Parties Congressional Campaign Committees in 2004." In The Election After Reform: Money, Politics and the Bipartisan Campaign Reform Act, edited by Michael Malbin. New York: Rowman and Littlefield Publishers, Inc.

Dwyre, Diane, and Robin Kolodny. 2014. "Party Money in the 2012 Elections." In Financing the 2012 Election, edited by David B. Magleby, 175-214. Washington, DC: Brookings Institution.

Francia, Peter, John Green, Paul Herrnson, Lynda Powell, and Clyde Wilcox. 2003. The Financiers of Congressional Elections: Investors, Ideologues, and Intimates. New York, NY: Columbia University Press.

Francia, P., J. Green, P. Herrnson, and L. Powell. 2005. "Limousine Liberals and Corporate Conservatives: The Financial Constituencies of the Democratic and Republican Parties.” Social Science Quarterly 86: 761-778.

Golob, Thomas. 2003(2001). "Structural Equation Modeling for Travel Behavior Research." Transportation Research. Part B: Methodological 37: 1-25.

Greenfield, James. 1999. Fund-Raising: Evaluation and Managing the Fund Development Process. New York: Wiley.

Grossmann, Matt. 2012. The Not-So-Special Interests: Interest Groups, Public Representation, and American Governance. Stanford, CA: Stanford University Press.

Heaney, Michael. 2010. "Linking Political Parties and Interest Groups." In The Oxford Handbook of American Political Parties and Interest Groups, edited by L. Sandy Maisel and Jeffrey M. Berry, 568-587. UK: Oxford University Press.

Herrnson, Paul. 2005. "Interest Groups and Campaigns: The Electoral Connection.” In The Interest Group Connection: Electioneering, Lobbying and Policymaking in Washington, edited by Paul S. Herrnson, Ronald G. Shaiko and Clyde Wilcox. Washington DC: CQ Press.

Herrnson, Paul. 2008. Congressional Elections: Campaigning at Home and in Washington. 5th ed. Washington DC: CQ Press.

Herrnson, Paul. 2009. "The Roles of Party Organizations, Party-connected Committees, and Party Allies in Elections.” Journal of Politics 71 (4): 1207-1224.

Herrnson, Paul. 2012. Congressional Elections: Campaigning at Home and in Washington. 6th ed. Thousand Oaks, CA: CQ Press.

Karol, David. 2009. Party Position Change in American Politics: Coalition Management. New York, NY: Cambridge University Press.

Kenny, David A. 2014. “Measuring Model Fit.” http://davidakenny.net/cm/fit.htm. Accessed January 10, 2014.

Key, V. O. 1954. Politics, Parties, and Pressure Groups. 5th ed. New York: Thomas Y. Crowell Company.

Koger, Gregory, Seth Masket, and Hans Noel. 2009. "Partisan Webs: Information Exchange and Party Networks." British Journal of Political Science 39: 633-653.

La Raja, Raymond. 2013. "Rich Parties, Better Parties? Party-Centered Campaign Finance Laws and American Democracy." The Forum 11: 313-338.

MacCallum, R. C., M. W. Browne, and H. M. Sugawara. 1996. "Power Analysis and Determination of Sample Size for Covariance Structure Modeling." Psychological Methods 1: 130-149.

Magleby, David. 2011a. "Political Parties and the Financing of the 2008 Elections." In Financing the 2008 Election, edited by David B. Magleby and Anthony Corrado. Washington DC: Brookings Institution. 
Magleby, David. 2011b. "Electoral Politics as a Team Sport: Advantage to the Democrats." In The State of the Parties: The Changing Role of Contemporary American Parties, edited by John Green and Daniel J. Coffey, New York, NY: Rowman and Littlefield Publishers.

Malbin, Michael J. 2006. "Assessing the Bipartisan Campaign Reform Act," In The Election After Reform: Money, Politics, and the Bipartisan Campaign Reform Act, edited by Michael Malbin. New York, NY: Rowman and Littlefield Publishers.

Masket, Seth. 2009. No Middle Group: How Informal Party Organizations Control Nominations and Polarized Legislatures. Ann Arbor: University of Michigan Press.

Potter, Trevor. 2006. "The Current State of Campaign Finance Law," In The New Campaign Finance Sourcebook, edited by Anthony Corrado, Thomas Mann, Daniel Ortiz, and Trevor Potters, Washington, DC: Brookings Institution Press.

Powell, Larry. 2010. "Political Parties and the Finance Law." In Campaign Finance Reform: The Political Shell Game, edited by Melissa Smith, Glenda Williams, Larry Powell and Gary Copeland. New York, NY: Lexington Books.

Price, Heather, and Jessica Collet. 2012. "The Role of Exchange and Emotion on Commitment: A Study of Teachers.” Working Paper.

Rozell, Mark, Clyde Wilcox, and David Madland. 2006. Interest Groups in American Politics: The New Face of Electioneering. Washington, DC: CQ Press.

Sabato, Larry. 1990. "PACs and Parties." In Money, Elections, and Democracy, edited by Margaret Latus Nugent and John R. Johannes. Boulder, CO: Westview Press.

Salant, Jonathan D. 2012. “Parties Raise Record Cash After 'Soft Money’ Ban: BGOV Barometer.” Bloomberg, 5 September. Accessed July 21, 2013. http://www.bloomberg.com/ news/2012-09-05/parties-raise-record-cash-after-soft-money-ban-bgov-barometer.html.

Schattschneider, E. E. 1941. Party Government. New York: Rhinehart and Company.

Skinner, Richard M. 2005. "Do 527s Add Up to a Party? Thinking About the 'Shadows' of Politics," The Forum 3: Article 5.

Smith, Melissa, and Larry Powell. 2013. Dark Money, Super PACs, and the 2012 Election. New York, NY: Lexington Books.

Sorauf, Frank. 1988. Money in American Elections. Boston, MA: Addison-Wesley Educational Publishers.

Taylor, Lincoln, and Craig Holman. 2010. "Fading Disclosure: Increasing Number of Electioneering Groups Keep Donors’ Identities Secret.” Public Citizen 9: 15.

Thomas, Clive. 2005. "The United States: The Paradox of Loose Party-Group Ties in the Context of American Political Development." In Political Parties and Interest Groups: Shaping Democratic Governance, edited by Clive S. Thomas. Boulder, CO: Lynne Rienner Publishers.

Treasury Inspector General for Tax Administration. 2013. Inappropriate Criteria Were Used to Identify Tax-exempt Applications for Review. Reference Number: 2013-10-053, 14 May.

White, Joseph. 2005. "Making Connections to the Appropriations Process." In The Interest Group Connection: Electioneering, Lobbying, and Policymaking in Washington, edited by Paul S. Herrnson, Ronald G. Shaiko, and Clyde Wilcox. Washington, DC: CQ Press.

Witko, Christopher. 2009. “The Ecology of Party-Organized Interest Relationships.” Polity 41: 211-234.

Dr. Anne Baker is an Assistant Professor of American Politics at Santa Clara University. Dr. Baker's research focuses upon money in politics as it relates to congressional elections and representation as well as political parties and interest groups. 
Copyright of Forum (2194-6183) is the property of De Gruyter and its content may not be copied or emailed to multiple sites or posted to a listserv without the copyright holder's express written permission. However, users may print, download, or email articles for individual use. 